\title{
Crude Oil Prices and Unemployment in South Africa: 1990 - 2010
}

\author{
Phakama Senzangakhona \\ Department of Economics, University of Fort Hare, \\ Email: psenzangakhona@ufh.ac.za \\ Ireen Choga \\ School of Economic \& Decision Sciences, North West University, South Africa. \\ Email: Ireen.Choga@nwu.ac.za
}

\section{Doi:10.5901/mjss.2015.v6n2p407}

\begin{abstract}
This study analyses and investigates the impact of crude oil price volatility on unemployment in South Africa. This is done by firstly surveying theoretical and empirical literature on the crude oil price-unemployment relationship before relating it to South Africa. Secondly, crude oil and unemployment trends with their causes are overviewed. The study employs a Johansen cointegration technique based on VAR to model unemployment against crude oil prices, real effective exchange rate, real interest rates and real gross domestic product. Using quarterly data for the period 1990-2010, econometric results show that crude oil prices are positively related to unemployment in the long run while the opposite is true in the short run. Parameter estimates and variables are statistically significant; hence there are also policy recommendations which are related to both empirical and theoretical literature. Lastly, impulse response functions show that unemployment returns to equilibrium in the long run when crude oil price changes whereas real interest rates followed by crude oil prices explain most of unemployment changes than other variables in the long run.
\end{abstract}

Keywords: Crude oil prices, unemployment, South Africa, Johansen, vector auto-regression (VAR).

\section{Introduction}

Crude oil price volatility mainly originates from international market forces while there is no independent economy immune from its effects. In addition, crude oil prices are denominated in US dollars. Further, petrol price in South Africa is linked to the price of crude oil in international markets, while international petrol prices are essentially driven by supply and demand for product in a particular market. Therefore, Crude oil prices combined with the Rand/Dollar exchange rate have a major impact on petrol prices, as they are determined in the New York and London future exchange.

The determination of crude oil prices is distinguished into three eras (Wakeford, 2006). The first era shows that crude oil prices were determined chiefly by multinational companies, while during the second era oil prices were determined by the Organisation of Petroleum Exporting Countries in the 1970s by influencing prices through its output decisions. The third and current era is the determination of crude oil prices using a market related pricing system which links crude oil prices to the market price of particular reference crude. According to Wakeford (2006) the most important and commonly used reference prices are Brent and West Texas Intermediate (WTI). However, crude oil price determination (supply and demand balance) is also dependent on; political factors, future markets, situational factors and climate change.

In order to trace the spillover effects of oil price fluctuations, macroeconomic transmission mechanism channels (two) of an oil price increase are used. The first channel shows the supply side shock effect where a rise in oil price slows down growth of output and slows down productivity. Since wages are nominal sticky downward, unemployment increases and impose further reduction in GDP and unexpected increase in inflation rate. The second channel shows the wealth transfer effect of rising oil prices which reveal the shift of purchasing power from oil importing countries to oil exporting countries. Consumer demand in oil importing countries declines while it increases in oil exporting countries. Further, world net demand for goods produced in oil importing countries is also reduced. According Nkomo (2006), such impacts vary according to the country's dependence on oil imports, and the country's energy and oil intensities.

South Africa is a major importer of crude oil and suffers a problem of persistent high levels of unemployment. It is against this background that this study seeks to examine the impact of crude oil price volatility on unemployment in South 
Africa. After analyzing the supply shock effect of crude oil prices the study seek to examine the relationship of crude oil prices and unemployment in South Africa. Therefore the study seek to investigate whether an increase in crude oil prices cause an increase in unemployment in South Africa during the period 1990-2010.

\section{Overview of Crude Oil Prices and Unemployment in South Africa}

Figure 2.1 below shows crude oil price and unemployment trends in South Africa for the perid 1990-2010. The average of crude oil prices was $\$ 36.18$ in 1990-2010, whereas unemployment rate on average was $23.6 \%$. The price of Brent crude oil increased from $\$ 23.43$ in 1990 to $\$ 79.54$ in 2010, where reasons are traced in the global economy and OPEC's output decisions (Heydova et.al 2011). On the other hand unemployment increased from 18.8\% to 24\% during the period 19902010 and the structural factors within the labour market being the major causes.

Figure 2.1 Crude Oil Prices and Unemployment in South Africa 1999-2010.

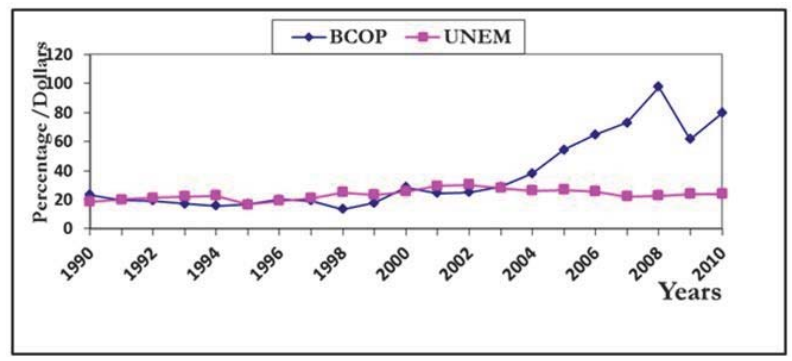

Source: Own graph compiled using Stats SA and SARB data (2012)

Figure 2.1 also shows that from 1990 to 1999 crude oil prices had declined from $\$ 23.43$ to $\$ 17.97$, with fluctuations during the period and the peak being reached in 1996 with $\$ 20.22$. On the other hand, unemployment had risen during the same period but the peaked reached in 1998 at 25\%. During the period 1999-2010, unemployment increased in a smaller scale but had drastic fluctuations during the course of the period. Figure 2.1 shows an increase from $23.35 \%$ in 1999 to $23.96 \%$ in 2010 with the peak and trough at $30.41 \%$ and $22.23 \%$ in 2002 and 2007 respectively. On the other hand, crude oil prices increased constantly from $\$ 24.47$ to $97.77 \%$ in 2001 to 2008 before declining shortly to $\$ 61.59$ in 2009 an increasing again in 2010 to $\$ 79.54$.

In a nutshell, Figure 2.1 show that from 1990-2010 unemployment would; increase with crude oil prices, increase while crude oil prices decline and decline while crude oil price are increasing. The determination of the exact relationship of crude oil prices and unemployment in section five will therefore prove vital.

\section{Review of Supporting Literature}

Theoretical literature that has been used in this study include: classical theory of unemployment, Keynesian theory of unemployment, Phillips Curve analysis and augmented Phillips Curve (natural rate) theory. The Classical and Keynesian theories had a consensus that (un)employment that the balance of aggregate demand and supply but the Keynesians could not agree that always occur at full employment level. Phillips Curve analysis was based on the negative relationship between unemployment and wage level (inflation) where a certain level of unemployment is achieved at a specific level inflation. Augmented Phillips Curve argues that consumer expectations (rational and adaptive) will actually keep (un)employment at a natural level in the long run where deviations exist only in the short run.

Researchers also wanted to validate theories through empirical findings and studied the impact of oil prices on unemployment while other researchers also expanded to other macro-economic variables. Certain results were different due to the nature of countries while others were conclusive. These studies are divided according to developed and developing countries, and also those based in South Africa. Research conducted in developed countries include the studies of Loschel and Oberndorfer (2009), Carruth et.al (1998), Andrepoulos (2006), Mellquist and Fermermo (2007), Stern (2000), Hamilton (1983), Mork et al (1994), Hooker (1996), and Jalles (2009). In developing countries, research includes the works of Papapetrou (2001), Robalo and Soldado (2008), Masih (2010), Chang et.al (2011), Taiwo et.al (2012), Bouchaour and Al-Zeaud (2012), Rafiq and Salim (2011), Khan (2010), Ito (2008), Sari and Soytas (2006), Syed 
(2010). On the other hand, Fofana et.al (2007) (2008), McDonald and Melt (2005), Essama-Nssah et.al (2007) studied the impact of oil prices on the South African economy.

\section{Methodology}

This study investigates the impact of crude oil price volatility on unemployment in South Africa by applying Johansen (1991, 1995) co-integration test based on the VAR methodology approach. This requires unit root testing; hence this study employs Augmented Dickey-Fuller and Phillips-Perron tests. In addition, error correction modelling is applied for short and long run co-integration test. Langrage-Multiplier, White-Cholesky and Jacque-Bera test are the only techniques used to perform diagnostics checks. Lastly, impulse response functions and variance decompositions are also performed in order to determine the most relative important variable in explaining unemployment changes, and how unemployment responds to changes/shocks in any of the independent variables specifically crude oil prices. The next section specifies the model.

\section{Specification of the Model}

The study adopted a model used by Löschel and Oberndorfer (2009) to investigate the impact of oil prices on unemployment in Germany However, this study modifies the model in order to investigate the impact of crude oil price volatility on unemployment in South Africa. Unemployment is a function of crude oil prices, real interest rate, real effective exchange rate and real gross domestic product. This is expressed as follows:

$U N E M=\beta_{0}+\beta_{1} C O P+\beta_{2} R I N T+\beta_{3} R E E R+\beta_{4} R G D P+\mu$

When variables are set into logarithms to avoid the effects of their trends, the model is specified as follows:

$L U N E M=\beta_{0}+\beta_{1} L C O P+\beta_{2} L R I N T+\beta_{3} L R E E R+\beta_{4} L R G D P+\mu$

LUNEM = Logarithm of unemployment in South Africa. This study uses unemployment based on the strict definition of unemployment. The study used absolute values of unemployment data in South Africa.

LCOP = Logarithm of crude oil prices in South Africa. Brent crude oil prices are expressed in US dollars.

LRINT $=$ Logarithm of real interest rates in South Africa.

LREER = Logarithm of real effective exchange rate in South Africa.

LRGDP = Logarithm of real gross domestic product in South Africa. This study used GDP at constant or base year prices (2000s).

This study uses a quarterly data covering the period 1990-2010. Unemployment data is obtained from Quantec and International Labour Organisation databases respectively. Crude oil prices, real effective exchange rate, real interest rates and gross domestic product are obtained from the SARB database where the real prime overdraft rate is used as a proxy for real interest rates. As stated earlier, the data is tested for stationarity using Augmented Dickey-Fuller and Phillips-Perron test and Table 1 presents results below.

Table 1: Unit Root Tests results

\begin{tabular}{|c|c|c|c|c|c|}
\hline & Unemployment & Crude oil price & Real interest rate & $\begin{array}{l}\text { Real effective exchange } \\
\text { rate }\end{array}$ & $\begin{array}{c}\text { Real Gross Domestic } \\
\text { Product }\end{array}$ \\
\hline \multicolumn{6}{|c|}{ ADF } \\
\hline Level & $2.669 *$ & 0.513 & 2.210 & 1.944 & 0.543 \\
\hline First Difference & $9.249 * \star \star$ & $8.462^{\star \star \star}$ & $6.125^{\star \star \star}$ & $8.478^{\star \star \star}$ & $9.051^{* \star \star}$ \\
\hline \multicolumn{6}{|c|}{$\mathrm{PP}$} \\
\hline Level & $2.677^{*}$ & 0.465 & $3.029 * \star$ & 1.993 & $2.589 *$ \\
\hline First Difference & $9.249 * \star \star$ & $7.608^{\text {*** }}$ & 12.109 & $8.480^{\star * \star}$ & $48.907^{\star \star \star}$ \\
\hline
\end{tabular}

The Augmented Dickey Fuller results in Table 1 reveal that when variables are in levels unemployment only becomes stationary at $10 \%$ significance level, while after first differencing all variables become stationary. However, Phillips-Perron test reveal that the hypothesis of unit root in the variables in levels could be rejected in the case of unemployment (at $10 \%$ significance level), real interest rate (at 5\%) and real gross domestic product (at 10\%). After first differencing, the PP test showed all variables to be stationary. All variables can now be assumed to be integrated of the same order, and therefore can be trusted for statistical purposes. 


\section{Interpretation of Results and Main Findings}

It is now assumed that variables are integrated in the same order, therefore co-integration tests can be performed. In order to address the difficulties associated with interpreting co-integration results of multiple regressions without omitting other variables, pairwise correlation matrix is applied. Table 2 below is a pairwise correlation matrix, in which it is shown that crude oil prices and real gross domestic product are negatively related to unemployment while real effective interest and real interest rates are positively related. This means an increase in crude oil price and real gross domestic product will cause a decline in unemployment while an increase in real interest and real effective exchange rates will lead to an increase in unemployment in South Africa.

Table 2. Pairwise-correlation matrix

\begin{tabular}{|c|c|c|c|c|c|}
\hline & LUNEM & COP & REER & RINT & LRGDP \\
\hline LUNEM & 1.000000 & -0.423140 & 0.409995 & 0.077235 & -0.454649 \\
\hline LCOP & -0.423140 & 1.000000 & -0.241396 & -0.428815 & 0.801713 \\
\hline LREER & 0.409995 & -0.241396 & 1.000000 & -0.044706 & -0.435357 \\
\hline LRINT & 0.077235 & -0.428815 & -0.044706 & 1.000000 & -0.256467 \\
\hline LRGDP & -0.454649 & 0.801713 & -0.435357 & -0.256467 & 1.000000 \\
\hline
\end{tabular}

The next step in the Johansen technique is to indicate a lag order and the deterministic trend assumption of the VAR. This is done by using the information criteria approach as a formula of choosing the lag order. Table 3 shows that four optimal lags are selected. Therefore, the Johansen cointegration test is performed using 4 lags for the VAR.

Table 5.4. Lag order selection criteria

\begin{tabular}{|c|c|c|c|c|c|c|}
\hline Lag & LogL & LR & FPE & AIC & SC & HQ \\
\hline 0 & -743.8451 & NA & 192.7018 & 19.45052 & 19.60272 & 19.51140 \\
\hline 1 & -489.3773 & 469.2782 & 0.497837 & 13.49032 & $14.40349^{*}$ & $13.85558^{\star}$ \\
\hline 2 & -460.4586 & 49.57499 & 0.453386 & 13.38853 & 15.06268 & 14.05818 \\
\hline 3 & -425.4176 & 55.51949 & 0.356668 & 13.12773 & 15.56285 & 14.10176 \\
\hline 4 & -398.1186 & $39.70759^{*}$ & $0.349741^{*}$ & $13.06802^{*}$ & 16.26411 & 14.34643 \\
\hline
\end{tabular}

*indicates the lag order selected by the criterion.

LR: sequential modified LR test statistic (each test at $5 \%$ level)

FPE: Final prediction error

AIC: Akaike information criterion

SC: Schwarz information criterion

HQ: Hannan-Quinn information criterion

Table 3 presents the Johansen co-integration test results using a much stricter (Trace) test which reveal that the hypothesis of none of the variables is co-integrated is rejected because the trace statistics of 76.985 is higher than critical value 69.818 at $5 \%$ significance level. However, Table 4 shows the maximum eigenvalue based Johansen co-integration test which reveal that there is no co-integrating vector at $5 \%$ level of significance. This is shown by the acceptance of the null hypothesis of no co-integrating vectors since the maximum eigenvalue test 32.784 is lower than critical value 33.876 .

Table 3. Unrestricted Co-integration Rank Test (Trace)

\begin{tabular}{|c|c|c|c|c|}
\hline Hypothesized No. of CE (s). & Eigenvalue & Trace Statistic & 0.05 Critical Value & Prob.** \\
\hline None * & 0.339655 & 76.98527 & 69.81889 & 0.0120 \\
\hline At most 1 & 0.259478 & 44.20081 & 47.85613 & 0.1058 \\
\hline At most 2 & 0.181307 & 20.46916 & 29.79707 & 0.3916 \\
\hline At most 3 & 0.057255 & 4.665557 & 15.49471 & 0.8433 \\
\hline At most 4 & 9.81E-05 & 0.007751 & 3.841466 & 0.9294 \\
\hline \multicolumn{5}{|c|}{$\begin{array}{l}\text { Trace test indicates } 1 \text { co-integrating eqn(s) at the } 0.05 \text { level } \\
\text { *denotes rejection of the hypothesis at the } 0.05 \text { level } \\
\text { **MacKinnon-Haug Michelis (1999) p-values }\end{array}$} \\
\hline
\end{tabular}


Table 4. Unrestricted Co-integration Rank Test (Maximum Eigenvalue)

\begin{tabular}{|c|c|c|c|c|}
\hline Hpothesized No. of CE (s). & Eigenvalue & Max-Eigen Statistic & 0.05 Critical Value & Prob.** \\
\hline None * & 0.339655 & 32.78446 & 33.87687 & 0.0671 \\
\hline At most 1 & 0.259478 & 23.73165 & 27.58434 & 0.1444 \\
\hline At most 2 & 0.181307 & 15.80360 & 21.13162 & 0.2365 \\
\hline At most 3 & 0.057255 & 4.657806 & 14.26460 & 0.7842 \\
\hline At most 4 & 9.81E-05 & 0.007751 & 3.841466 & 0.9294 \\
\hline \multicolumn{5}{|c|}{$\begin{array}{l}\text { Max-eigenvalue test indicates no co-integration at the } 0.05 \text { level } \\
{ }^{*} \text { denotes rejection of the hypothesis at the } 0.05 \text { level } \\
\star \star \text { MacKinnon-Haug-Michelis (1999) p-values }\end{array}$} \\
\hline
\end{tabular}

In the previous section it has been established that co-integration exists, therefore a VECM can be used. Further, short run and long run impacts of the variables have to be distinguished in order to determine the extent of the influence that crude oil prices has on unemployment using VECM. Table 5 shows long run effects of explanatory variables on unemployment as illustrated in equation 3.

Table 6. Long run co-integration equation results

\begin{tabular}{|c|c|c|c|}
\hline Variable & Co-efficient & Standard error & t-statistic \\
\hline Constant & 44.95706 & - & - \\
\hline LUNEM & 1.000000 & - & - \\
\hline COP & 0.043528 & 0.01028 & 4.23603 \\
\hline RINT & 0.249456 & 0.04519 & 5.51994 \\
\hline REER & -0.024502 & 0.00950 & -2.57788 \\
\hline LRGDP & -4.426349 & 1.45422 & -3.04380 \\
\hline
\end{tabular}

The long run impact of crude oil price volatility on unemployment is also shown using equation 3 below:

$U N E M=44.957+0.044$ COP + 0.249RINT - 0.025REER - 4.426RGDP

Equation (3) shows that crude oil prices (COP), real interest rate (RINT) are positively related to unemployment, while the real effective exchange rate and real gross domestic product (RGDP) are negatively related to unemployment. All variables are statistically significant because their respective absolute t-statistic values are greater than 2 . Equation 3 suggests that a unit increase in crude oil prices increases unemployment approximately by 0.044 . On the other hand, a unit increase of real interest rate increases unemployment approximately by 0.249 while a unit increase of real effective exchange in the long run decreases unemployment approximately by 0.025 . Lastly, the unit increase of real gross domestic product decreases unemployment approximately by 4.426 in the long run. Evidence of how errors amongst variables are corrected in the short run is presented in Table 7.

Table 7. Error correction model results

\begin{tabular}{|c|c|c|c|}
\hline Variable & Co-efficient & Standard error & t-statistics \\
\hline$U(-1)$ & -0.056064 & 0.02922 & -1.91885 \\
\hline $\mathrm{D}($ LCOP $)$ & -2.696975 & 2.44114 & -1.10480 \\
\hline $\mathrm{D}($ LRINT) & -1.517522 & 1.47167 & -3.97011 \\
\hline $\mathrm{D}($ REER $)$ & -1.737168 & 0.38224 & -1.18041 \\
\hline $\mathrm{D}($ LRGDP $)$ & 0.017999 & 0.03117 & 0.57744 \\
\hline
\end{tabular}

The co-efficient of the error term (-0.056) in Table 7 shows that the speed at which unemployment adjusts to changes in its equilibrium level is 6 per cent. Therefore the deviation of unemployment from equilibrium is corrected at $6 \%$ in one quarter as the unemployment moves towards restoring equilibrium. This speed of adjustment is statistically insignificant with an absolute t-value of -1.919 . The moderate speed of adjustment by unemployment in South Africa reflects the effect and impact of other factors affecting unemployment which are not specified in the model. All explanatory variables except RGDP are negatively related to unemployment.

A unit increase in crude oil prices, real interest and effective exchange rates leads to a decrease of unemployment approximately by 2.697 (COP), 1.518 (RINT), 1.737 (REER). On the other hand a unit increase of real gross domestic 
product increases unemployment approximately by 0.017 . This shows a phenomena called jobless growth in South Africa. All variables show statistical insignificance except real interest rates.

It is also essential in this study to validate the particular evaluation of the outcomes achieved by the model. This is done by using diagnostics checks as presented in Table 8. Langrange Multiplier is used to test for serial correlation, White test for heteroskedascity and Jarque-Bera test for normality. Results show that residuals are; not serial correlated, are not heteroskestic and are normally distributed among variables. This is shown by p-values greater than 0.05 units.

Table 5.8. Diagnostics checks results

\begin{tabular}{|l|l|c|c|}
\hline Test & Null Hypothesis & t-statistics & Probability \\
\hline Langrange Multiplier(LM) & No serial correlation & 17.066 & 0.8794 \\
\hline White (Ch-sq) & No conditional heteroscedascity & 684.984 & 0.0637 \\
\hline Jarque-Bera (JB) & There is a normal distribition & 1.427 & 0.4898 \\
\hline
\end{tabular}

Since this study focuses on the impact of crude oil prices volatility on unemployment in South Africa, only the responses of unemployment to changes in unemployment, oil prices and other variables will be considered. In other words, how other variables react to changes from other variables is not considered. Figure 2 presents these responses

Figure 2. Impulse response of unemployment

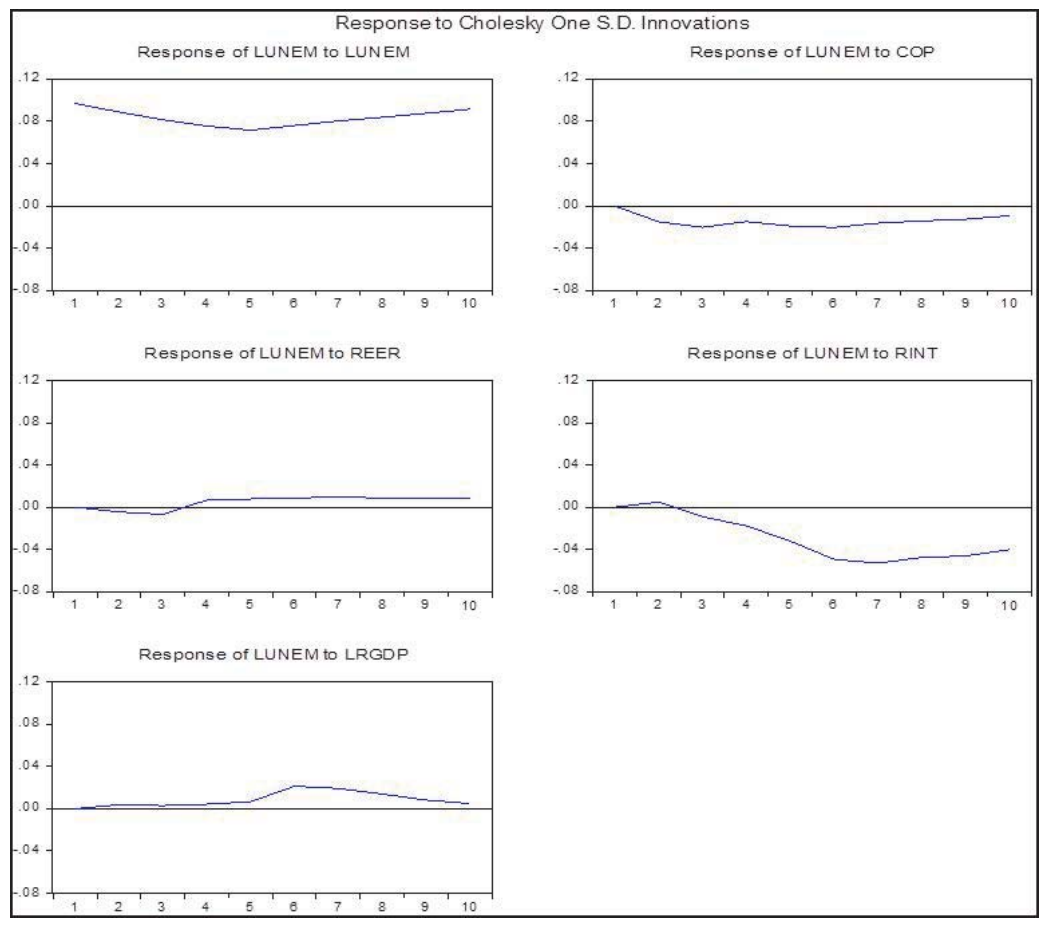

Unemployment responds with a decline to oil price shocks in the first quarter before increasing after three quarters, and remain level for one quarter but decreases for two quarters and increase from the sixth quarter in returning to the equilibrium. This means it takes a relative medium term for unemployment to return to equilibrium after crude oil price shocks. In the case of real effective exchange rate changes, unemployment starts to decline in the first quarter to the third quarter and returns to equilibrium in the third and half quarter before increasing until the fourth quarter. The trend dies out from the fifth quarter onwards. On the other hand, an increase in unemployment after a shock in real interest rate occurs from the first to the second quarter before returning to equilibrium. It returns to equilibrium in the second quarter and starts to decline until the seventh, where the decline dies out during the eighth quarter. This also shows unemployment takes a long-term to return to equilibrium after changes in RINT. Lastly, when shocks are experienced on the real gross domestic product, unemployment gradually increases from the first to the second quarter and remains level until the third quarter before increasing with a wide margin from the fifth to the sixth quarter. The trend dies out after the fifth quarter 
whilst it does not move towards the equilibrium.

Variance decompositions are also performed with results presented in Table 9. According to Brooks (2008), variance decomposition illustrates the proportion of the movements in the dependent variables that are due to their own shocks, versus shocks to other variables. Brooks (2008) suggested that in the first period, any changes in the dependent variable are explained by its own innovations (shocks), hence unemployment explains $100 \%$ of its variance in the first period. However, moving to the fifth period, unemployment explains its variations by 92.25 per cent while the other variables explain only the remaining 7.75 per cent. Out of the remaining $7.75 \%$, crude oil prices explained $3.27 \%$ of unemployment's changes, while the real effective exchange rate explained $0.46 \%$, real interest rates explained $3.80 \%$ and the real gross domestic product explained $0.23 \%$. Further, unemployment explains about $80.68 \%$ of its variations in the tenth period while the remaining $19.12 \%$ is explained by other variables. Of this crude oil prices explained $2.73 \%$ of unemployment variations, the real effective exchange rate explained $0.62 \%$, real interest rates explained $14.60 \%$ and real gross domestic product explained only $1.36 \%$ of unemployment variations.

Table 9. Variance decomposition results

\begin{tabular}{|c|c|c|c|c|c|c|}
\hline Period & S.E. & LUNEM & COP & REER & RINT & LRGDP \\
\hline 1 & 0.096817 & 100.0000 & 0.000000 & 0.000000 & 0.000000 & 0.000000 \\
\hline 2 & 0.132417 & 98.37931 & 1.294042 & 0.107645 & 0.134976 & 0.084026 \\
\hline 3 & 0.157130 & 96.63371 & 2.598662 & 0.258202 & 0.415632 & 0.093795 \\
\hline 4 & 0.176020 & 95.38596 & 2.781633 & 0.353837 & 1.343625 & 0.134942 \\
\hline 5 & 0.193901 & 92.24933 & 3.266476 & 0.455775 & 3.802198 & 0.226218 \\
\hline 6 & 0.216189 & 86.54798 & 3.517026 & 0.520676 & 8.270796 & 1.143521 \\
\hline 7 & 0.238167 & 82.67822 & 3.378062 & 0.614474 & 11.75049 & 1.578752 \\
\hline 8 & 0.257792 & 81.12989 & 3.190516 & 0.629772 & 13.41254 & 1.637279 \\
\hline 9 & 0.276618 & 80.45986 & 2.982487 & 0.627399 & 14.42182 & 1.508434 \\
\hline 10 & 0.294338 & 80.68255 & 2.734837 & 0.624999 & 14.59752 & 1.360088 \\
\hline
\end{tabular}

This study allows the variance decompositions for ten quarters so as to create a long run phenomenon and thereby allowing all independent variables to affect unemployment for a longer term.

In a nutshell, unemployment explains most of its variations in the short run followed by real interest rates and crude oil prices. Further, unemployment explains most of its variations followed by real interest rates and crude oil prices before real gross domestic product and the real effective exchange rate even in the long run. Therefore, with the use of variance decompositions it can be argued that real interest rates followed by crude oil prices are the most important variables in explaining unemployment in South Africa over the study period.

\section{Conclusions and Policy Recommendations}

This study considered unemployment as a function of crude oil prices, real interest rate, real effective exchange rate and real gross domestic product. The main findings revealed that crude oil prices and real interest rates are positively related to unemployment, while real effective exchange rate and real gross domestic product are negatively related to unemployment in South Africa.

Based on empirical results and their theoretical implications, policy recommendations are raised in this study. The exchange rate policy intervention is recommended against the effects implicit to crude oil prices and real effective exchange rates as both variables are directly related to exchange rate. Exchange rate target and currency depreciation through monetary institutions are the main tools in which unemployment can be handled in association to the impacts of crude oil prices and real effective exchange rate.

The positive relationship between real interest rate and unemployment is also evident in the monetary policy transmission mechanism analysis of the channels. Therefore, this study recommends that the use of inflation targeting by the central bank (SARB) should strive to keep interest low in the long run as that would lead to increased investment and decline in unemployment. However, in the short run the money market has to be allowed to clear and determine interest rates on its own. Lastly, policy implications that are focused on increasing output and thereby decreasing unemployment in South Africa should be directed to labour-intensive industries with a main of increasing productivity. 


\section{References}

Andreopoulos. S, (2006), The Real Interest Rate, the Real Oil Price, and US Unemployment Revisited. PhD dissertation at Birkbeck College, University of London.

Brooks. C, (2008), Introductory Econometrics for Finance, Cambridge University Press

Brown. S.P.A and Yucel. M.K, (2002), Energy prices and aggregate economic activity: an interpretative survey, Quartely Review of Economics.

Carruth A, Hooker M, and Oswald A, (1998), Unemployment Equilibria and Input Prices: Theory and Evidence from the United States. Review of Economics and Statistics 80, pp. 621-628.

Chang Y, Jha K, Fernandez K M and Jam'an N F, (2011) "Oil Price Fluctuations and Macroeconomic Performances in Asian and Oceanic Economies" [Online] Available:http://www.usaee.org/usaee2011/submissions/Online Proceedings/Chang\%20et\%20al_ Full\%20Paper.[Accessed on 21 September 2012]

Dickey, D. A and W. A Fuller, (1979). Distribution of the Estimators for Autoregressive Time Series with a Unit Root, Journal of the American Statisticsl Association, 74 p 427-431.

Essama-Nssah B, Go D, Kearney M, Korman V, Robinson S, and Thierfelder K, (2007), Economy-wide and Distributional Impacts of an Oil Price Shock on the South African Economy, Policy Research Working Paper 4354, Washington D.C.: The World Bank.

Fofana I, Mabugu R, and Chitiga M, (2007), Oil Prices and the South African Economy: Macro-Meso-Micro Modelling Approach, Report Prepared for the Financial and Fiscal Commission, South Africa.

Hamilton J, (1983), Oil and the macroeconomy since World War II, Journal of Political Economy 91, 228-248.

Hooker M A, (1996), What Happened to the Oil Price-Macroeconomic Relationship?, Journal of Monetary Economics 38 (1996), 195-213

Ito K, (2008), Oil Price and the Russian Economy: A VEC Model Approach. International Research Journal of Finance and Economics, $17,68-74$..

Jalles J.T, (2009), Do Oil Prices Matter? The Case of a Small Open Economy. Annuals of economics and finance ,10(1), 65-87.

Khan S, (2010), Crude Oil Price Shocks to Emerging Markets: Evaluating the BRICs Case, Munich Personal RePEc Archive, Paper No. 22978

Löschel A, Oberndorfer U, (2009), Oil and Unemployment in Germany, ZEW Discussion Papers, No. 08-136, [Online] Available at: http://hdl.handle.net/10419/27619 [Accessed on 25 July 2012]

McDonald S, Melt van S ,(2005), A Computable General Equilibrium (CGE) Analysis of the Impact of an Oil Price Increase in South Africa, Working Paper Series from PROVIDE Project No 15633

Mork K. A, (1994), Business Cycles and the Oil Market, Energy Journal 15 Special Issue: 15-38.

Nkomo, J C, (2006), Crude oil price movements and their impact on South Africa, Energy Research Centre, University of Cape Town.

Papapetrou E, (2001), Oil price shocks, stockmarket, economic activity and employment in Greece, Energy Economics 23, 511-532.

Robalo P. B, Salvado J. C, (2008), Oil Price Shocks and the Portuguese Economy Since 1970s,FEUNL Working Paper Series No. 529, [Online] Available at: http://ssrn.com/abstract=13091172. [Accessed on June 2012]

Salim R, Rafiq S, (2011), The impact of crude oil price volatility on selected Asian emerging economies, Hoque, Tanzil (ed), Global Business and Social Science Research Conference, Jun 20-21 2011, pp. 1-33. Beijing, China: World Business Institute Australia

Sari R, Soytas U, (2006), The relationship between stock returns, crude oil prices, interest rates, and output: evidence from a developing economy Turkey, The Empirical Economics Letters 5 (4), 205-220.

Stern D.I, (2000), A multivariate cointegration analysis of the role of energy in the US macro-economy. Energy Economics 22, $267-283$.

Syed N, (2010), Measuring the Impact of Changing Oil Prices and other Macro Economic Variables on GDP in theContext of Pakistan's Economy, International Research Journal of Finance and Economics , 52, $41-49$.

Taiwo M, Taiwo A, Olowookere D, (2012), Crude Oil Price, Stock Price and Some Selected Macroeconomic Indicators: Implications on the Growth of Nigeria Economy, Research Journal of Finance and Accounting ISSN 2222-1697 (Paper) ISSN 2222-2847 Vol 3, No 2, 2012 [Online] Available at: http://www.iiste.org/, [Accessed on 12 February 2013].

Wakeford J.J, (2006), The impact of oil price shocks on the South African macroeconomy: History and prospect. 